\title{
Young guns shoot to the top in China's research revolution
}

\section{David Cyranoski, Beijing}

As older scientists retire and research rapidly expands, a large number of young scientists in China are being thrust into prominent positions.

This year, for example, the Institute of Biophysics in Beijing, part of the Chinese Academy of Sciences (CAS), has hired 13 new group leaders with an average age of less than 40 . The institute's director, 52-year-old Zihe Rao, says that he plans to bring in another 20 young group leaders as most of the current senior investigators retire over the next couple of years.

Other CAS institutes and some university departments are adopting a similar strategy. China's readiness to thrust researchers into senior positions in their $30 \mathrm{~s}$ - when, it is often said, most great scientists do their best work - contrasts with the trouble that other

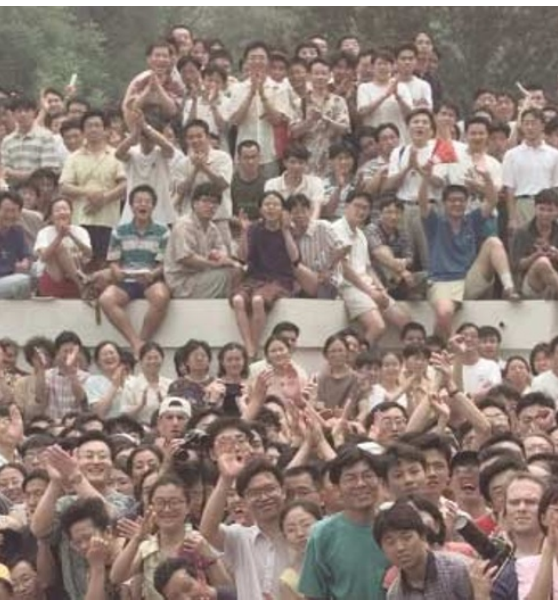

Youth culture: students at Peking University help to feed the expansion of China's science base.

scientific powers, including Japan and the United States, have experienced in creating opportunities for young researchers in their prime (see Nature 421, 680; 2003).

The fast track being taken by many young researchers in China is a product of two factors: the rapid expansion of research in the country, and the lack of established, middleaged scientists from a generation whose best talent was squandered during Chairman Mao's Cultural Revolution, which began in 1966. There followed ten years during which scientists and other intellectuals were sent to labour on collective farms.

Surveys of the age distribution of Chinese researchers, presented two weeks ago at the ninth biannual International Conference on Scientometrics and Informetrics in Beijing, clearly demonstrate the revolution's impact on China's scientifically active population. Bihui Jin, of the CAS Documentation and
Information Centre, presented data at the meeting which show that as recently as 1995 , there was a 'hump' of older scientists whose training predated the turmoil of the late 1960s. Now that older generation has retired, leaving a demographic that is dominated by youth. "This is clearly a result of the Cultural Revolution," says Jin.

Now, as the post-revolution scientists are coming into their prime, the Chinese government has taken a keen interest in promoting science, encouraging institutional leaders to invest in talented young researchers. "They gave me the green light," says Rao, many of whose recruits have only recently returned to China after travelling abroad for training. The United States, for example, welcomed students who left China in the wake of the failed revolt against the government in Tiananmen Square in 1989.

Enge Wang, director of the CAS Institute of Physics, says that his group leaders two-thirds of whom are still in their $30 \mathrm{~s}$ are bursting with youthful enthusiasm. "Half of them will be at the laboratory until 11 at night. It's a very open and energetic atmosphere," he says.

Much of the talent that is emerging now resulted from China's struggle to rebuild its intellectual élite during the 1980s and 1990s. Government projects, with names such as the National Distinguished Youth's Science Foundation and the One Hundred Talent Project, were set up to cultivate young scientific talent, and to attract trained researchers back home from the United States and Europe, Jin says. As these projects bear fruit, the country's premier research institutions are raising their standards. In the past six years, for example, the CAS and Tsinghua University have begun to insist that newly hired professors have PhDs.

Zhu Chen, a biologist and vice-president of the CAS, says that he is happy to see all this youthful vigour, but is also a little apprehensive about giving promising people, such as Rao's 33-year-old deputy director, too much responsibility. "It would be better to have some accomplished leaders in their 50 s and 60 s to let the young people do their work," he argues.

Jin's data also forecast another cloud on the horizon. As of the late 1990s, a dip in the number of researchers in their late 20s and early 30s suggests that a large number of young scientists have moved overseas. But if the past is any guide, many of these researchers will still play a role in China's flourishing research community, either by returning to their homeland or by collaborating with scientists who work there.

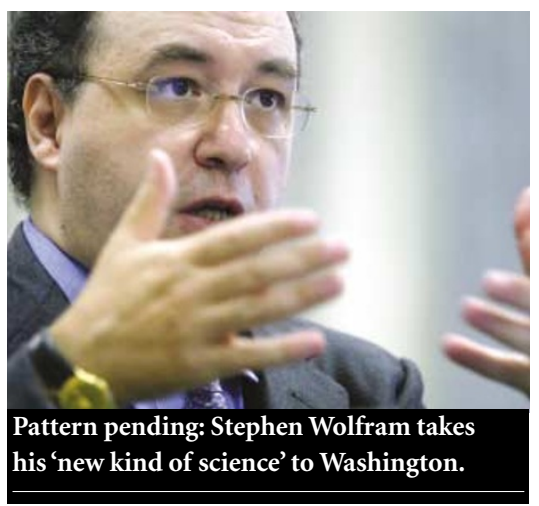

Esoteric theorist lands starring role in Senate hearing

Geoff Brumfiel, Washington

For the past 15 months, mathematician Stephen Wolfram has been packing university lecture halls with people eager to hear about his 'new kind of science'. But on 4 September, he addressed an audience unlike any he's had before a US Senate subcommittee, whose chairman has expressed an interest in providing public funding for his work.

Wolfram made waves in May 2002, when he published A New Kind of Science. The book describes how feeding simple sets of rules into a computer can generate remarkably complex patterns. The author theorizes that these results can be used to describe virtually everything from the patterns on mollusc shells to the fabric of space-time (see Nature 417, 216-218; 2002). Scientists, however, have given the book mixed reviews.

To date, Wolfram has privately funded his research and the publication of his book. But the publicity surrounding A New Kind of Science has caught the attention of Sam Brownback (Republican, Kansas), who chairs the Senate commerce committee's subcommittee on science, technology and space.

Brownback is one of the more conservative members of the Senate, and has clashed with scientists on issues such as embryonic-stem-cell research and the teaching of creationism in the classroom. He was the only senator to attend the hourlong hearing, at which Wolfram explained why he believes that his computergenerated patterns might benefit the fields of physics, biology and nanotechnology.

It is unclear which US research agency might be responsible for following this up, but Brownback seems committed to finding a home for Wolfram's research. "It seems like this work could have enormous potential," he told Nature after the hearing. "If it's right, then the government should be investing in it." 